\title{
Five considerations for the transposition and application of Article 17 of the DSM Directive
}

Eleonora Rosati*

The Author

Eleonora Rosati is Professor of Intellectual Property Law and Director of the Institute for Intellectual Property and Market Law (IFIM) at Stockholm University and Editor of the Journal of Intellectual Property Law \& Practice.

\section{This Article}

- Directive 2019/790 on copyright in the Digital Single Market was adopted in 2019. Member States have until 7 June 2021 to transpose its provisions into their own national laws. Of the various provisions which are part of the directive, Article 17 has been and remains one of the most intensively and intensely discussed ones.

- This brief commentary takes position in respect of five key points concerning the transposition and application of Article 17: (1) the nature of its right of communication to the public; (2) the possibility for Member States to envisage de minimis exclusions; (3) the nature of exceptions or limitations in paragraph 7; (4) ex ante blocking of content and the role of the complaint and redress mechanism in paragraph 9; and (5) the position of users whose content has been unduly blocked.

- It maintains that: (1) the right of communication to the public in Article 17 is the same right as found in the rest of the acquis; (2) Member States cannot introduce statutory de minimis exclusions; (3) the exceptions and limitations under Article 17(7) have mandatory character, require adopting a minimalistic transposition method, and should interpreted uniformly across the EU; (4) ex ante blocking is allowed and the complaint and redress mechanism serves inter alia to reinstate unduly blocked content; and (5) users are entitled to invoke protection under available exceptions and limitations, although those cannot be characterized as user rights.

\section{Introduction}

Directive 2019/790 on copyright in the Digital Single Market ${ }^{1}$ (DSM Directive) was adopted in 2019, at the end of a process that had officially begun in 2016, when the Commission unveiled its original proposal. ${ }^{2}$ The DSM Directive pursues the same objectives as the pre-existing acquis (recital 2), including to: guarantee a high level of protection for rightholders (e.g., InfoSoc Directive ${ }^{3}$ ); streamline rights

\footnotetext{
*Email: eleonora@e-lawnora.com. This article builds upon a contribution published under the same title on The IPKat (https://ipkitten.blogspot.com/) on 16 February 2021.

1Directive (EU) 2019/790 of the European Parliament and of the Council of 17 April 2019 on copyright and related rights in the Digital Single Market and amending Directives 96/9/EC and 2001/29/EC, OJ L 130, 17.5.2019, pp. 92-125

2 Proposal for a Directive of the European Parliament and of the Council on copyright in the Digital Single Market, COM/2016/0593 final - 2016/0280 (COD).

${ }^{3}$ Directive 2001/29/EC of the European Parliament and of the Council of 22 May 2001 on the harmonisation of certain aspects of copyright and related rights in the information society, OJ L 167, 22.6.2001, pp. 10-19. The principle that protection must be at a high level is stated explicitly in both the InfoSoc Directive (recitals 4 and 9) and the Enforcement Directive (recital 10 of Corrigendum to Directive 2004/48/EC of the European Parliament and of the Council of 29 April 2004 on the enforcement of intellectual property rights (OJ L 157, 30.4.2004), OJ L 195, 2.6.2004, pp. 16-25), and is also implied in recital 5 of the Rental and Lending Rights Directive (Directive 2006/115/EC of the European Parliament and of the Council of 12 December 2006 on rental right and lending
} 
clearance (Collective Rights Management Directive ${ }^{4}$ ); and create a level playing field for the exploitation of works and other protected subject matter. In turn, recital 2 links such objectives to the establishment and functioning of the EU internal market, as well as to both an incentive-based view of copyright (as a stimulus to innovation, creativity, investment and production of new content) and the Union's objective to respect and promote culture (including by bringing European common cultural heritage to the fore) and cultural diversity, in accordance with Article 167(4) of the Treaty on the Functioning of the European Union. ${ }^{5}$ Recital 3 adds to all this the need to: remedy the interpretative uncertainties raised by technological advancement and the emergence of new business models and actors, as well as the objective of ensuring that the former is not unduly restricted as a result of such uncertainties; and guarantee a wellfunctioning and fair marketplace for goods incorporating and services based on copyright works and other protected subject matter. The latter is in particular the objective at the heart of Article 17, which concerns the use of protected content by online content-sharing service providers (OCSSPs).

The rationale underlying the adoption of Article 17 is indeed rooted within remedying what in jargon and also through the legislative debate - came to be referred to as 'value gap' or 'transfer of value'. Like other provisions in the Directive, Article 17 is aimed at strengthening the position of rightholders vis-á-vis OCSSPs and contributing to the realization of one of the key objectives of the Directive, that is achieving a "fair marketplace" (recital 3). Recital 61 acknowledges, in the first place, the growing relevance of online content-sharing services within the increasingly complex online content market. OCSSPs, as defined in Article 2, have become a main source of access to content online. On the one hand, they allow for wider access to cultural and creative works, offer opportunities for related industries to develop new business models, and enable diversity and ease of access to content. On the other hand, they also pose challenges when protected content is uploaded without prior authorization from rightholders. The same recital also acknowledges the legal uncertainty surrounding whether OCSSPs engage in copyright-relevant acts and need to obtain authorization from rightholders for content uploaded by their users who do not hold any relevant rights in such content, without prejudice to the application of exceptions and limitations provided for in EU law. That uncertainty further affects the ability of rightholders to obtain appropriate remuneration for the use made by OCSSPS of works and other subject matter to which they own the rights.

A detailed analysis of Article 17 is provided elsewhere. ${ }^{6}$ This brief commentary is limited to tackling five key points regarding Article 17 and takes position in the context of a debate in which contrasting and - in some cases - highly polarized views have been presented. They are:

1. The nature of the right of communication to the public in Article 17;

2. The possibility for Member States to envisage de minimis exclusions from the application of Article 17;

3. The nature of exceptions or limitations in Article 17(7);

4. Ex ante blocking of content and the role of the complaint and redress mechanism in Article 17(9);

5. The position of users whose content has been unduly blocked.

\section{The nature of the right of communication to the public in Article 17}

Also because of the approaches in certain implementation drafts at the national level, an important debate that has emerged further to the adoption of the DSM Directive is that concerning the legal nature of the

right and on certain rights related to copyright in the field of intellectual property (codified version), OJ L 376, 27.12.2006, pp. 28-35).

4 Directive 2014/26/EU of the European Parliament and of the Council of 26 February 2014 on collective management of copyright and related rights and multi-territorial licensing of rights in musical works for online use in the internal market, OJ L 84, 20.3.2014, pp. 72-98.

${ }^{5}$ Consolidated version of the Treaty on the Functioning of the European Union, OJ C 326, 26.10.2012, pp. 47-390.

${ }^{6}$ E Rosati, Copyright in the Digital Single Market - Article-by-Article Commentary to the Provisions of Directive 2019/790 (OUP:2021), in press. 
provision vis-à-vis Article 3 of the InfoSoc Directive. Some commentators have argued that the nature of Article 17 would be that of a special right or even a new sui generis right. In turn, this latter interpretation would mean that national legislatures would not be bound to comply with the list of exceptions and limitations in Article 5 of the InfoSoc Directive and could even introduce their own exceptions or limitations to the right of communication to the public under Article 17.7

In his 2020 Opinion in the pending YouTube/Cyando cases, Advocate General Saugmandsgaard Øe held the view that, whilst the platforms at issue in those references (YouTube and cyberlocker Uploaded) would be liable in principle under Article 17 lacking a licence, the same would not be true under Article 3 of the InfoSoc Directive alone. In this sense, Article 17 of the DSM Directive would be a novel regime without retroactive application. ${ }^{8}$

The Draft Commission Article 17 Guidance states that, based on the wording of recital 64, Article 17 would be a lex specialis to Article 3 of the InfoSoc Directive and Article 14 of the Ecommerce Directive. ${ }^{9}$ As such, Member States would not be able to rely, in their transpositions of Article 17, on their earlier implementations of either directive with regard to the notion of 'authorization' or 'communication to the public'. ${ }^{10}$

As discussed at greater length elsewhere ${ }^{11}$, this understanding of the relationship between the InfoSoc and DSM directives should be rejected, including by the Court of Justice of the European Union (CJEU) when it decides YouTube/Cyando. The relationship between these two directives is special only insofar as the treatment of certain liability aspects is concerned:

- First, save for what is provided for in Article 24, Article 1(2) of the DSM Directive lists the InfoSoc Directive among the pieces of EU legislation that are left intact and in no way affected by it;

- Secondly, recital 64 states that the DSM Directive clarifies that providers that satisfy the definition of OCSSP do perform copyright-restricted acts, including acts of communication/making available to the public. It does not suggest that only providers that fall under the notion of OCSSPs may perform acts of communication to the public or other restricted acts;

\footnotetext{
${ }^{7}$ M Husovec and J Quintais, 'How to license Article 17? Exploring the implementation options for the new EU rules on content-sharing platforms' (2020), available at https://papers.ssrn.com/sol3/papers.cfm?abstract id=3463011 (last accessed 17.02.2021). See also JP Quintais, 'The new copyright in the Digital Single Market Directive: a critical look' (2020) 42(1) EIPR 28, p. 37, and C Angelopoulos, 'Primary and accessory liability in EU copyright law', in E Rosati (ed), The Routledge Handbook of EU Copyright Law (Routledge:2021), p. 212.

8 Opinion of Advocate General Saugmandsgaard Øe in YouTube, C-682/18 and C-683/18, EU:C:2020:586, at [66][93]. See E Rosati, 'The AG Opinion in YouTube/Cyando: a regressive interpretation of the right of communication to the public' (27.07.2020) The IPKat, available at https://ipkitten.blogspot.com/2020/07/the-ag-opinion-inyoutubecyando.html (last accessed 17.02.2021). See also B Hanuz, 'Direct copyright liability as regulation of hosting platforms for the copyright-infringing content uploaded by their users: Quo vadis?' (2020) 11(3) JIPITEC, available at https://www.jipitec.eu/online-first-articles-1/5174 (last accessed 17.02.2021), \41, considering this part of the Opinion convincing, though regarding (at \$66) the interpretation by the Advocate General of recital 27 in the preamble to the InfoSoc Directive 2001/29 "strained". For a summary of the Opinion's content, see G Smith, "Advocate General advises CJEU on copyright liability of online sharing platforms' (2020) 15(11) JIPLP 857.

${ }^{9}$ Directive 2000/31/EC of the European Parliament and of the Council of 8 June 2000 on certain legal aspects of information society services, in particular electronic commerce, in the Internal Market, OJ L 178, 17.7.2000, pp. 116.

${ }^{10}$ European Commission, 'Targeted consultation addressed to the participants to the stakeholder dialogue on Article 17 of the Directive on Copyright in the Digital Single Market' (2020), available at https://ec.europa.eu/newsroom/dae/document.cfm?doc_id=68591 (last accessed 17.02.2021), p. 3.

${ }^{11}$ E Rosati, 'The legal nature of Article 17 of the Copyright DSM Directive, the (lack of) freedom of Member States and why the German implementation proposal is not compatible with EU law' (2020) 15(11) JIPLP 874.
} 
- Thirdly, still from recital 64, it follows that the concept of communication/making available to the public referred to - and not defined - in the DSM Directive does neither alter the corresponding notion in other EU legislation nor does it affect the application of Article 3 of the InfoSoc Directive (or, e.g., Article 8 of the Rental and Lending Rights Directive) to providers other than OCSSPs.

All the above indicates that the concept of communication/making available to the public in Article 17 is to be interpreted in accordance with the corresponding concept in inter alia the InfoSoc Directive. In addition, settled case law provides that identical concepts in different directives should be attributed the same meaning. ${ }^{12}$ Article 17 does not create a 'sub-category' of the communication to the public right in Article 3 of the InfoSoc Directive or a sui generis right: it is the same right. In turn, this means that Member States are not entitled to alter the scope thereof or to introduce exceptions or limitations to Article 17 beyond what EU law does allow. ${ }^{13}$

\section{De minims exclusions}

To fall within the application of Article 17, an information society service provider (ISSP) must inter alia "store and give access to a large amount of copyright-protected works or other protected subject matter uploaded by its users" (emphasis added). Like the original Commission's proposal, the DSM Directive does not define the notion of 'large amount'. Recital 63 clarifies that the assessment of whether an ISSP stores and gives access to a large amount of copyright works and other protected subject matter is to be conducted on a case-by-case basis and take account of a combination of elements, including - but not necessarily limited to - the audience of the service and the number of files of protected subject matter uploaded by the users of such service.

Some commentators have suggested that this part of the provision would allow Member States' legislatures "to introduce certain nuances with regard to de minimis activities". ${ }^{14}$ However, nowhere does the text of the Directive envisage such possibility: national legislatures are not allowed to alter the scope of Article 17 by, e.g., introducing statutory de minimis exclusions. ${ }^{15}$ What the notion of 'large amount' does allow is solely for national courts to determine, based on the circumstances at issue and subject to fulfilling the other requirements under the notion of OCSSP, whether the ISSP at hand does in fact qualify as an OCSSP. All this is of course without prejudice to the application of the (recital 66) "specific liability mechanism" (not a safe harbour, as some commentators have instead called it ${ }^{16}$ ) in Article 17(4), subject to satisfying all the relevant conditions therein.

${ }^{12}$ For examples specifically in the copyright field, see: Luksan, C-277/10, EU:C:2012:65, at [85]; Football Association Premier League, C-403/08 and C-429/08, EU:C:2011:631, at [187]-[188]; UsedSoft, C-128/11, EU:C:2012:407, at [60]; Mc Fadden, C-484/14, EU:C:2016:689, at [36].

13 In this sense, see also Association Littéraire et Artistique Internationale, Draft Second Opinion on Certain Aspects of the Implementation of Article 17 of Directive (EU) 2019/790 of 17 April 2019 on Copyright and Related Rights in the Digital Single Market (18.09.2020), available at https://www.alai.org/en/assets/files/resolutions/200918-second-opinion-article17-dsm draft en.pdf (last accessed 17.02.2021), $\$ 2$.

${ }^{14}$ A Metzger - M Senftleben (on behalf of the European Copyright Society), Comment of the European Copyright Society on Selected Aspects of Implementing Article 17 of the Directive on Copyright in the Digital Single Market into National Law (2020), available at https://europeancopyrightsocietydotorg.files.wordpress.com/2020/04/ecs-comment-article-17cdsm.pdf (last accessed 03.02.2021), p. 2.

15 In substantially the same sense, see also JP Mochon and Others, Les Outils de Reconnaissance des Contenus sur les Plateformes Numériques de Partage: Propositions pour la Mise en Cuvre de l'Article 17 de la Directive Européenne sur le Droit d'Auteur (15.12.2020 - 19.01.2021), available at https://www.culture.gouv.fr/Sites-thematiques/Propriete-litteraire-etartistique/Conseil-superieur-de-la-propriete-litteraire-et-artistique/Travaux/Missions/Mission-du-CSPLA-sur-lesoutils-de-reconnaissance-des-contenus-et-des-oeuvres-sur-les-plateformes-de-partage-en-ligne-II (last accessed 17.02.2021), pp. 56-60.

${ }^{16}$ Cf M Peguera, 'The new Copyright Directive: Online Content-Sharing Service Providers lose eCommerce Directive immunity and are forced to monitor content uploaded by users (Article 17)' (26.09.2019) Kluwer Copyright Blog, available at http://copyrightblog.kluweriplaw.com/2019/09/26/the-new-copyright-directiveonline-content-sharing-service-providers-lose-ecommerce-directive-immunity-and-are-forced-to-monitor-content- 


\section{The nature of the exceptions or limitations in Article 17(7)}

Article 17(7) requires Member States to introduce or maintain in their laws exceptions or limitations for quotation, criticism, review and uses for the purpose of caricature, parody or pastiche. These are for the benefit of users when uploading and making available content generated by them on OCSSPs' services. Three points are worth noting here: the first is the requirement of a fair balance between contrasting rights and interests; the second is the relationship between Article 17(7) and the InfoSoc exceptions or limitations; the third is the freedom left to Member States.

Insofar as the first point is concerned, Recital 70 (see also recital 84) specifically refers to the need to strike a balance between the fundamental rights laid down in the EU Charter of Fundamental Rights ${ }^{17}$, in particular freedom of expression (Article 11) and freedom of the arts (Article 13), and the right to property, including intellectual property (Article 17). This said, in light of CJEU case law ${ }^{18}$, users are not entitled to invoke directly the application of the Charter rights and freedoms, lacking a specific copyright exception or limitation at both the EU level and in the applicable national law adopted in compliance with EU law. All this is without prejudice to the possibility that Article 17(7) is regarded as a provision having vertical direct effect in the event that a Member State has failed to transpose one of the exceptions or limitations therein into its own legal system. ${ }^{19}$

Turning to the second issue, the exceptions or limitations under points a and $b$ of Article 17(7) are the same as those that already exist under the EU acquis (Article 5(3)(d) and (k) of the InfoSoc Directive). What is different, however, is the character of such exceptions and limitations: whilst exceptions or limitations are optional under the InfoSoc Directive (with the exclusion of temporary copies in Article 5(1) therein), under the DSM Directive they are mandatory for Member States to maintain or introduce, though solely for the purpose of Article 17 and, more precisely, for content generated and uploaded by users. In no way does Article 17(7) suggest that the exceptions or limitations in Article 5(3)(d) and (k) of the InfoSoc Directive have now a general mandatory character. Member States shall of course remain free to maintain or transpose into their own national laws the other exceptions or limitations in the InfoSoc Directive, which shall apply - where relevant - to inter alia the situations covered by Article 17.

Finally, the language of Article 17(7) is highly prescriptive. In this sense, it requires Member States to adopt a minimalistic method of transposition. ${ }^{20}$ With regard to exceptions and limitations, this means that Member States are, on the one hand, required to introduce or maintain national exceptions or limitations allowing quotation, criticism, review, and uses for the purpose of caricature, parody or pastiche insofar as activities falling within the scope of the provision are concerned. A Member State does not enjoy the freedom to, say, introduce an exception for quotation but refrain from also introducing an exception for parody in relation to uses under Article 17. All these concepts are also autonomous concepts of EU law, which must be interpreted uniformly throughout the EU, having regard to the context of the provision and the objective pursued by the legislation in question. This conclusion follows from the need for

uploaded-by-users-article-17/ (last accessed 17.02.2021); SF Schwemer, 'Article 17 at the intersection of EU copyright law and platform regulation' (2020) (forthcoming) NIR, pre-print available at https://www.researchgate.net/publication/342833693 Article 17 at the Intersection of EU Copyright Law an d Platform Regulation (last accessed 17.02.2021), p. 14.

${ }^{17}$ Charter of Fundamental Rights of the European Union, OJ C 326, 26.10.2012, pp. 391-407.

18 Spiegel Online, C-516/17, EU:C:2019:625, at [49]; Funke Medien, C-469/17, EU:C:2019:623, at [64].

${ }^{19}$ On the vertical direct effect of EU directives, see van Duyn, Case 41-74, EU:C:1974:133, at [12]. On the requirements for direct effect, see the seminal decision in van Gend \& Loos, Case 26-62, EU:C:1963:1.

${ }^{20}$ See, in general, the discussion in R Král, 'On the choice of methods of transposition of EU Directives' (2016) 41(2) EL Rev 220. With specific regard to copyright, see E Rosati, Copyright and the Court of Justice of the European Union (OUP:2019), pp. 73-74. 
uniform application of EU law and from the principle of equality. ${ }^{21}$ On the other hand, as stated, Member States do not have the discretion to introduce any exceptions or limitations beyond those expressly allowed under Article 5 of the InfoSoc Directive, which maintain - save for Article 5(1) - their optional character. In this sense, Article 25 allows Member States to adopt or maintain broader exceptions or limitations to harmonized rights, but only insofar as the resulting provisions comply with inter alia the InfoSoc Directive: in other words, there is freedom within the limits of the acquis, not beyond it.

\section{Ex ante blocking and complaint and redress mechanism}

Article 17(7) states that the cooperation between OCSSPs and rightholders shall not lead to preventing the availability of works or other subject matter uploaded by users, which do not infringe copyright and/or related rights, including - but not limited to (the work or other subject matter or parts thereof may not be protected in the first place, e.g., because the term of protection has expired or the relevant requirements for protection are not fulfilled) - where such works or other subject matter are covered by an exception or limitation. Article 17(7) does not expressly state that 'legitimate uses' should be allowed ex ante, rather than just expost by relying on the redress and complaint mechanism sub Article 17(9), nor does it clarify what the legal consequences would be if a user was prevented from uploading and making available content which qualifies for protection under Article 17(7).

With regard to ex ante blocking of user-uploaded content, it would be obviously preferable that, in principle, legitimate content was not blocked by the technologies applied by OCSSP. This position is in line with that expressed by the Commission Draft Article 17 Guidance. This said, the text of the Directive is such that it is also acceptable for a Member State - from the point of view of compliance with Article 17 obligations - only to introduce a complaint and redress mechanism and not also a system of ex ante safeguards, as long as the complaint and redress mechanism is effective and expeditious. ${ }^{22}$ Recital 70 indeed clarifies that the complaint and redress mechanism shall entail human review and serve in particular - though not exclusively - to users where they could benefit from an exception or limitation to copyright in relation to an upload (i) access to which has been disabled or (ii) that has been removed. Member States are required to ensure that out-of-court redress mechanisms are also available for the disputes that are outstanding further to an unsuccessful complaint.

\footnotetext{
${ }^{21}$ See, in general, Ekro, C-327/82, EU:C:1984:11, at [11]. In the field of copyright and relates rights, see: Opinion of Advocate General Tizzano in SENA, C-245/00, EU:C:2002:543, at [32]; SENA, C-245/00, EU:C:2003:68, at [24] and [34]; SGAE, C-306/05, EU:C:2006:764, at [31]; Infopaq, C-5/08, EU:C:2009:465, at [27]-[29]; Padawan, C-467/08, EU:C:2010:620, at [37]; VEWA, C-271/10, EU:C:2011:442, at [25]-[26]; Opinion of Advocate General Jääskinen in Airfield and Canal Digitaal, C-431/09, EU:C:2011:157, at [50]; Football Association Premier League, C-403/08 and C429/08, EU:C:2011:631, at [154]; DR and TV2 Danmark, C-510/10, EU:C:2012:244, at [34]; Opinion of Advocate General Bot in UsedSoft, C-128/11, EU:C:2012:234, at [51]; Donner, C-5/11, EU:C:2012:370, at [25]; UsedSoft, C128/11, EU:C:2012:407, at [40]; Opinion of Advocate General Cruz Villalón in Deckmyn, C-201/13, EU:C:2014:458, at [35]; Deckmyn, C-201/13, EU:C:2014:2132, at [15]; Dimensione Direct Sales and Labianca, C-516/13, EU:C:2015:315, at [22]; Reprobel, C-572/13, EU:C:2015:750, at [35]; Opinion of Advocate General Wahl in Microsoft Mobile Sales, C110/15, EU:C:2016:326, at [43]; EGEDA, C-470/14, EU:C:2016:418, at [38]; Opinion of Advocate General Saugmandsgaard Øe in ITV, C-275/15, EU:C:2016:649, at [65]; ITV, C-275/15, EU:C:2017:144, at [18]; Opinion of Advocate General Wathelet in Levola Hengelo, C-310/07, EU:C:2018:618, at [38]-[39]; Levola Hengelo, C-310/07, EU:C:2018:899, at [38]; Opinion of Advocate General Szpunar in Cofemel, C-683/17, EU:C:2019:363; at [25]; Cofemel, C-683/17, EU:C:2019:721, at [29]; Spiegel Online, C-516/17, EU:C:2019:625, at [62]; Opinion of Advocate General Tanchev in Atresmedia Corporación de Medios de Comunicación, C-147/19, EU:C:2020:597, at [65]. See further E Rosati, Copyright and the Court of Justice of the European Union (OUP:2019), pp. 42-43.

${ }^{22}$ In this sense, see also JP Mochon and Others, Les Outils de Reconnaissance des Contenus sur les Plateformes Numériques de Partage: Propositions pour la Mise en CEuvre de l'Article 17 de la Directive Européenne sur le Droit d'Auteur (15.12.2020 19.01.2021), available at https://www.culture.gouv.fr/Sites-thematiques/Propriete-litteraire-et-artistique/Conseilsuperieur-de-la-propriete-litteraire-et-artistique/Travaux/Missions/Mission-du-CSPLA-sur-les-outils-dereconnaissance-des-contenus-et-des-oeuvres-sur-les-plateformes-de-partage-en-ligne-II (last accessed 17.02.2021), pp. 66-66. Contra P Keller, 'Article 17: (Mis)understanding the intent of the legislator' (28.01.2021) Kluwer Copyright Blog, available at http://copyrightblog.kluweriplaw.com/2021/01/28/article-17-misunderstanding-the-intent-ofthe-legislator/ (last accessed 17.02.2021).
} 
It is not thus correct to maintain that the EU legislature would have intended that the preventive measures that an OCSSP is obliged to take under 17(4) to avoid liability can only ever or mainly be taken expost. Rather, the history of Article 17 shows that EU legislature found that users' fundamental rights and freedoms would be appropriately safeguarded by: (i) the provision that a licence obtained by an OCSSP also covers, at certain conditions, users' activities; (ii) the mandatory character of certain exceptions and limitations; and (iii) the provision of a process whereby an uploader, who considers that their uploads have been wrongly blocked, has access to swift and effective redress mechanism so as to ensure they can benefit from a relevant exception or limitation.

\section{Users whose content has been unduly blocked}

Insofar as the legal consequences of preventing lawful uploads are concerned, one possible interpretation might be to regard the exceptions or limitations referred to therein as rights of the users, with the result that preventing the availability of works or other subject matter uploaded by users, which do not infringe copyright and/or related rights, would qualify as an infringement of user rights. Whilst supported by the language of some CJEU decisions ${ }^{23}$ and scholarly commentary ${ }^{24}$, this interpretation does however neither reflect the wording of the Directive nor its rationale: neither Article 17(7) nor recital 70 refer to the exceptions or limitations for quotation, criticism, review, caricature, parody, and pastiche as 'rights'. Furthermore, the Directive per se does not attach any particular consequences to limitations or impediments to users when performing these activities, save for the possibility - under the redress and complaint mechanism - to request that content that qualifies for protection under such exceptions or limitations is reinstated in accordance with Article 17(9). In light of the foregoing, it is thus appropriate to characterize the exceptions or limitations under Article 5 of the InfoSoc Directive, which Article 17(7) expressly refers to, not as 'rights' of users, but rather as exceptions or limitations with a mandatory character, insofar as the activities that fall under the scope of application of Article 17 are concerned.

\section{Conclusion}

It is sufficient to read the ten paragraphs that compose Article 17 (as well as the accompanying recitals) to realize that this is a complex provision, the final text of which is the result of both a lengthy process and a number of compromises. However, it is now part of the EU acquis and Member States should not (and indeed may not) unduly alter the scope thereof, with the risk of interfering with the legislative action of EU legislature and creating further fragmentation in the single market. What the provision does clearly mandate is for national courts and authorities to base their judgements on the specific circumstances at issue and ensure that the balance set at the EU level is properly safeguarded, including with regard to users and their activities.

In this sense, and as a final note, the challenge launched by Poland to Article 17 before the CJEU reflects some substantial and important concerns. ${ }^{25}$ This Member State is seeking the annulment of Article 17(4)(b) and Article 17(4)(c), in fine (i.e. the part containing the following wording: "and made best efforts to prevent their future uploads in accordance with point (b)") of the DSM Directive. In the

23 Spiegel Online, C-516/17, EU:C:2019:625, at [54]; Funke Medien, C-469/17, EU:C:2019:623, at [70]. See also (albeit more timidly): Padawan, C-467/08, EU:C:2010:620, at [43]; Painer, C-145/10, EU:C:2011:798, at [132]; Deckmyn, C201/13, EU:C:2014:2132, at [26]. More explicitly: Ulmer, C-117/13, EU:C:2014:2196, at [31] and [43].

${ }^{24}$ See, e.g.: JP Quintais, 'The new copyright in the Digital Single Market Directive: a critical look' (2020) 42(1) EIPR 28, p. 39; JP Quintais and Others, 'Safeguarding user freedoms in implementing Article 17 of the Copyright in the Digital Single Market Directive: Recommendations from European academics' (2019) 10(3) JIPITEC, available at https://www.jipitec.eu/issues/jipitec-10-3-2019/5042 (last accessed 17.02.2021), §12; A Metzger - M Senftleben (on behalf of the European Copyright Society), Comment of the European Copyright Society on Selected Aspects of Implementing Article 17 of the Directive on Copyright in the Digital Single Market into National Law (2020), available at https://europeancopyrightsocietydotorg.files.wordpress.com/2020/04/ecs-comment-article-17-cdsm.pdf (last accessed 17.02.2021), p. 10; S Karapapa, 'The quotation exception under EU copyright: Paving the way for user rights' in E Rosati (ed) The Routledge Handbook of EU Copyright Law (Routledge:2021), p. 257; M Borghi, 'Exceptions as users' rights?', in E Rosati (ed) The Routledge Handbook of EU Copyright Law (Routledge:2021), pp. 263-280.

25 Republic of Poland v European Parliament and Council of the European Union, C-401/19 (in progress). 
alternative, should the Court find that the contested provisions could not be deleted from Article 17 without substantively changing the rules contained in the remaining provisions of that article, Poland requested that the Court annul Article 17 in its entirety. The action is based on an alleged breach of the right to freedom of expression and information as inter alia guaranteed by Article 11 of the EU Charter of Fundamental Rights. Specifically, Poland submitted that the imposition on OCSSPs of an obligation to make best efforts to ensure the unavailability of specific works and other subject matter, for which the rightholders have provided the relevant and necessary information (Article 17(4)(b)), and to prevent future uploads of protected works or other subject matter, for which the rightholders have submitted a sufficiently substantiated notice (Article 17(4)(c)), make it necessary for those service providers — in order to avoid liability — to carry out prior automatic verification (filtering) of content uploaded online by users, and therefore make it necessary to introduce preventive control mechanisms. Such mechanisms would allegedly undermine the essence of the right to freedom of expression and information and fail to comply with the requirement that limitations imposed on that right be proportional and necessary. As stated, the action brought by Poland reflects substantial and important concerns. These, however, relate to the application of the provision, not its very existence. As such, they should be left to national courts and authorities to address. Article 17 in itself is not contrary to the Charter rights. 